\title{
A Computational Study of the Acid Dissociation in the Sulfonamide Group
}

Fernando M. Carvalho ${ }^{1(\mathrm{PG}) *}$, Alessandra S. Kiametis ${ }^{2(\mathrm{PQ})}$, Mônica A. Silva ${ }^{2(\mathrm{PQ})}$, Yuri A. Oliveira $^{1(\mathrm{PG})}$, Ricardo Gargano ${ }^{1}$

${ }^{1}$ Universidade de Brasília, Instituto de Física, Campus Darcy Ribeiro.

${ }^{2}$ Universidade de Brasília, Instituto de Ciências Biológicas, Campus Darcy Ribeiro.

Palavras-chave: Sulfonamides, study computational, drug design, pKa.

The sulfonamides constitute an important class of drugs with widely uses like antibiotic, anti-diabetic, diuretics, anticonvulsants, stimulant and others [1, 2]. Sulfa drugs were first antibiotics to be used systemically after revolution in medicine, on the other hands, nowadays your results stand out with just 3\% adverse reactions when treated with antimicrobial agents [3, 4]. Biological activities are connected with chemical structure and physicochemical properties like $\mathrm{pKa}$ (the logarithm of negative acid dissociation constant) $[5,6]$. pKa value is crucial to development of drug design mainly when a functional group is not modified [6,7]. In this study, 19 molecules composed by sulfonamide group were optimized using M06-2X/6-311+G(d,p) and UM06-2X/6-311+G(d,p) levels to neutral and deprotonated molecules, respectively [8]. Then, we perform an investigation about the level of theory of calculations and basis set functions that can describe accurately the $\mathrm{pKa}$ values of these molecules. The obtained results were compared with the experimental data. From this comparison, it was possible to indicate the the best level of calculation and basis set functions to describe this class of molecules. Furthermore, this study indicate also how the radicals modify the pKa values. These features are very important to in-silico drug design.

\section{References}

[1] S. M. Mathews, V. Jiju, I. Thomas, J. T. Panicker, and L. S. Kuriakose, "World journal of pharmaceutical research," 2015.

[2] R. J. Henry, "The mode of action of sulfonamides," Bacteriological reviews, vol. 7, no. 4, p. 175, 1943.

[3] D. Bovet, Une chimie qui guérit: histoire de la découverte des sulfamides, vol. 13. Payot, 1988.

[4] H. Otten, "Domagk and the development of the sulphonamides," Journal of Antimicrobial Chemotherapy, vol. 17, no. 6, pp. 689-690, 1986.

[5] S. Babić, A. J. Horvat, D. M. Pavlović, and M. Kaštelan-Macan, "Determination of pka values of active pharmaceutical ingredients," TrAC Trends in Analytical Chemistry, vol. 26, no. 11, pp. 1043-1061, 2007.

[6] M. Remko, "Molecular structure, pka, lipophilicity, solubility and absorption of biologically active aromatic and heterocyclic sulfonamides," Journal of Molecular Structure: THEOCHEM, vol. 944, no. 1-3, pp. 34-42, 2010.

[7] M. Thakur, A. Thakur, P. V. Khadikar, and C. T. Supuran, "Qsar study on pka vis-àvis physiological activity of sulfonamides: a dominating role of surface tension (inverse steric parameter)," Bioorganic \& medicinal chemistry letters, vol. 15, no. 1, pp. 203209, 2005.

[8] C. Soriano-Correa, C. Barrientos-Salcedo, M. Francisco-Márquez, and C. I. SainzDíaz, "Computational study of substituent effects on the acidity, toxicity and chemical reactivity of bacteriostatic sulfonamides," Journal of Molecular Graphics and Modelling, vol. 81, pp. 116-124, 2018. 